\title{
Discovery of Macrotarsomys bastardi at Beza Mahafaly Special Reserve, southwest Madagascar, with observations on the dynamics of small mammal interactions
}

\author{
Ibrahim Antho Youssouf Jack ${ }^{\mid *}$ and \\ Emilienne Rasoazanabary*
}

\author{
Correspondence: \\ Emilienne Rasoazanabary \\ Department of Anthropology, University of Massachusetts \\ 240 Hicks Way \\ Amherst, Massachusetts 01003 \\ E-mail: rasmie@acad.umass.edu
}

\begin{abstract}
We report the presence of Macrotarsomys bastardi, Bastard's big-footed mouse, at the Beza Mahafaly Special Reserve in southwestern Madagascar. Despite years of fieldwork, including field research targeting the nocturnal mammals, this species had never been reported here previously. A program of intensive and random capture of nocturnal mammals was established over a period of one year (October 2006 to September 2007). We monitored the relative abundances and microhabitat preferences of small-bodied nocturnal mammals in three forests at Beza, as reflected in trapping success both on the ground and at heights of one to two meters in the trees. Three species are common at Beza (although they have different apparent habitat preferences): Microcebus griseorufus, Rattus rattus, and Echinops telfairi. Endemic rodents appear to be rare. Possible interactions between introduced rodents (rats and mice) and endemic species of rodents (Macrotarsomys and Eliurus) are also discussed.
\end{abstract}

\section{RÉSUMÉ}

Après plusieurs années de recherches dans la Réserve spéciale de Bezà Mahafaly au Sud-ouest de Madagascar, y compris les recherches sur les mammifères nocturnes, la présence de Macrotarsomys bastardi (famille des Nesomyidae) est signalée pour la première fois dans cet endroit. Une série d'échantillonnage et une séance de capture intensive des espèces nocturnes ont été organisées durant une année dans trois forêts différentes de cette région (entre octobre 2006 et septembre 2007). Les pièges avaient été installés sur le sol ou sur des branches à une hauteur comprise entre un et deux mètre(s) pour évaluer l'abondance relative et la préférence pour des microhabitats des micromammifères nocturnes. Trois espèces, ayant chacune des préférences particulières pour un type d'habitat, sont fréquentes à Bezà Mahafaly, à savoir Microcebus griseorufus, Rattus rattus et Echinops telfairi. Les rongeurs endémiques sont rares (Macrotarsomys et Eliurus), fait qui pourrait s'expliquer par leur interaction avec les rongeurs introduits (rats et souris) qui est discuté ici.

KEYWORDS: Macrotarsomys bastardi, Beza Mahafaly, Rodentia, Eliurus myoxinus, Nesomyidae

\section{INTRODUCTION}

Three species of rodents, including two introduced species (Rattus rattus and Mus musculus, superfamily Muroidea, family Muridae) and one endemic species (Eliurus myoxinus, superfamily Muroidea, family Nesomyidae) have been previously reported at Beza Mahafaly Special Reserve (BMSR) in southwestern Madagascar (S2341'20", E44³4'20") (Ratsirarson et al. 2001, Ratsirarson 2003). We report for the first time the presence in the reserve of a second endemic rodent, Macrotarsomys bastardi, Bastard's big-footed mouse (family Nesomyidae).

This species was previously recorded at a number of localities in southwestern Madagascar not far from Beza Mahafaly but never in the reserve itself. Its published distribution includes Sept Lacs along the Onilahy River, Toliara (north of Beza Mahafaly, see Rasoma and Goodman 2007) and north of the Onilahy River, in the regions of St. Augustin and along the Fiherenana River (Route Nationale 7, regions of Zombitse and Isalo; Carleton and Schmidt 1990, Jansa et al. 2008). It also occurs in both primary and degraded forests in the central highlands, southeast of the Mangoky, in the regions of Ihosy and Midongy (Rakotondravony 1996). It has been captured at Tsimanampetsotsa National Park, which is located to the southwest of Beza Mahafaly (Goodman et al. 2002). Indeed, the species is distributed along the southern and western coasts of Madagascar, from the region of Fort Dauphin (in the southeast) to the region of the Sofia River (Belambo) in the northwest (Garbutt 2007, Jansa et al. 2008).

Given this broad geographic distribution, this species has been accorded a 'low risk' conservation status (IUCN 2008) However, its survival at particular localities may be threatened due to human-induced environmental change or to the possible effects of introduced rodents (especially Rattus rattus), and it is imperative that interactions between humans, endemic rodents, and rats are better understood. During the year October 2006-September 2007, we captured rodents (murids and nesomyids), tenrecs (Echinops telfairi), and primates (Microcebus griseorufus) in several forests at Beza Mahafaly (including protected and unprotected habitats). This was the first intensive effort to document the populations of rodents at this site. Beza Mahafaly was established as a protected area in 1986 (Ratsirarson et al. 2001).

I Département des Sciences Biologiques, Université de Toliara, Madagascar, BP 407, Toliara, Madagascar and Reserve Special de Beza Mahafaly Betioky Sud, Toliara, Madagascar, E-mail: jackyantho@yahoo.fr

* These two authors are contributing equally 


\section{VOLUME 3 ISSUE 1

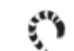 DECEMBER 2008 MADAGASCAR \%, CONSERVATION \& DEVELOPMENT}

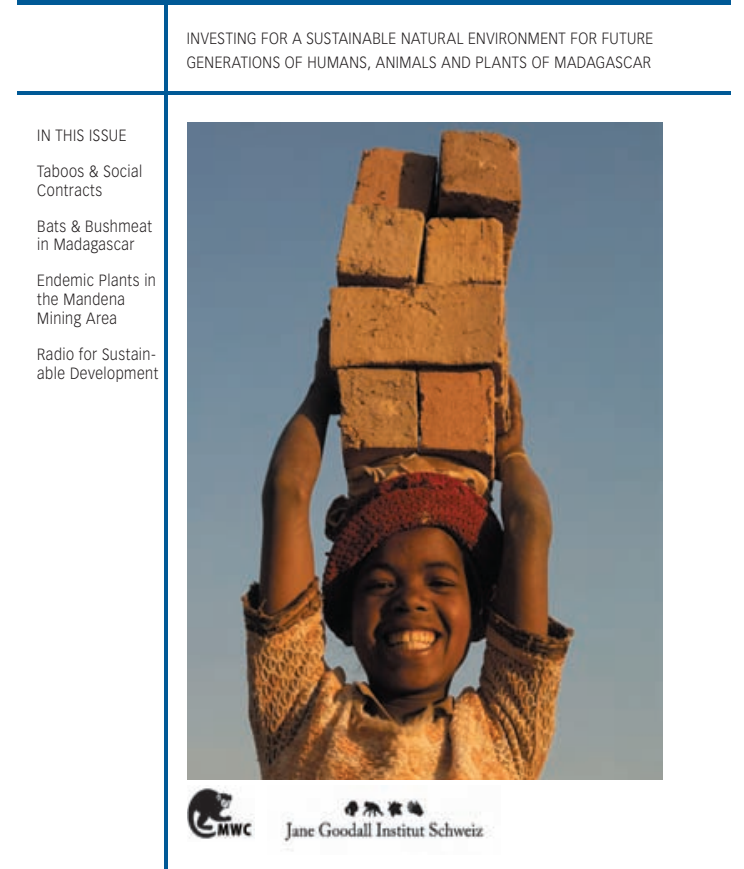

Madagascar Conservation \& Development is the journal of Madagascar Wildlife Conservation (MWC) and the Jane Goodall Institute (JGI Switzerland). It is produced in these institutions' own responsibility.

All the Issues and articles are freely available at http://www.mwc-info.net/en/services/journal.htm

Contact Journal MCD

info@journalmcd.net for general inquiries MCD funding@journalmcd.net for supporting the journal

Journal Madagascar Conservation \& Development Institute and Museum of Anthropology University of Zurich

Winterthurerstrasse 190

$\mathrm{CH}-8057$ Zurich, Switzerland

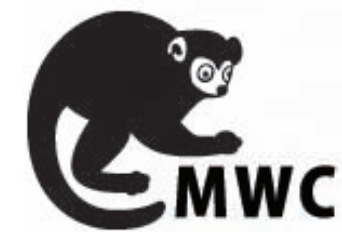

contact@mwc-info.net for general inquiries

Postfach 2701

CH-8021 Zürich, Switzerland

Logement 11, Cité Andohaniato Antananarivo 101, Madagascar

info@janegoodall.ch for general inquiries JGI

\section{$2 \pi$}

Jane Goodall Institut Schweiz
Switzerland

Postfach 2807

8033 Zürich, Switzerland 


\section{METHODS}

Beza Mahafaly is ecologically diverse, with a 90 ha Parcel 1 comprised partially of gallery forest and bordered along its eastern limit by a small river (the Sakamena, which is dry for around seven months every year). There is also a 520 ha spiny forest (Parcel 2) approximately $10 \mathrm{~km}$ to the west of Parcel 1 (Ratsirarson et al. 2001). Both parcels belong to the reserve, but only Parcel 1 has been fenced. Parcel 1 is considerably smaller in size than Parcel 2, and it is located near the main research camp. The fence was erected to keep cattle from entering this part of the reserve. The two are connected by a transitional dry forest corridor. Another dry forest is located near a village, Ihazoara, just southeast of Parcel 1, but that forest is not part of the reserve. Within a distance of around 20 kilometers from Parcels 1 and 2 are situated 17 villages with a combined human population of over 5,700 individuals (ca. 60\% children) (unpublished records of the Commune Rurale Ankazombalala). According to the records of the Beza Mahafaly research station (the camp site, located just to the south of Parcel 1), the reserve attracts around 70 tourists and 30 researchers annually. Figure 1 shows a schematic map of the Reserve (Parcels 1 and 2) and several of the nearby villages, including Ihazoara. The forest at Ihazoara is located to the east and south of the village.

Trapping occurred on a regular basis between 9 October 2006 and 30 September 2007. All captures were conducted at night, when these animals are active. Four months were scheduled for intensive sampling (October, January, May, and September) and all other months were scheduled for random sampling. This schedule was established to best sample individuals at very different times during the year, including the beginning of the wet season (October) and the middle of the wet season (January), the middle of the dry season (May), and the end of the dry season (September). During the periods of intensive sampling, we set 180 Sherman traps every night at each of three forests at Beza Mahafaly, Parcel 1 (gallery, protected), Parcel 2 (spiny, protected) and Ihazoara (dry, unprotected). The trapping in October extended until November 8, so each period of inten- sive capture encompassed 30 days. Sherman traps are made of aluminum $(7.7 \mathrm{~cm} \times 7.7 \mathrm{~cm} \times 30.5 \mathrm{~cm})$ with a spring-operated front door. All trapping locations were flagged and their positions recorded using GPS. During the months of intensive capture, the traps were set on every day of every week in grids measuring $275 \mathrm{~m} \times 225 \mathrm{~m}$. They were set at distances 25 meters apart; 60 trees had only one trap set at heights of one to two meters, 30 had two traps set in the tree (one at ca. one meter and a second at ca. two meters height), and 30 had a single trap set in the tree (again at between one and two meters) and a second trap set on the ground near the tree's base. The total number of traps set each night at each forest location was 180, equaling 5,400 trap-nights per month of intensive capture at each location. Traps were baited with banana at $1730 \mathrm{~h}$ and checked at 0500-0600h in the morning. When they were occupied, the animals were brought to the camp for measurement (weight, head length, body length, tail length, total foot length, and ear length), and for the collection of biological samples (blood, fur, ear tissue, feces, external parasites). To facilitate the collection of morphometric data and the marking procedure (cutting small pieces of ear tissue), individuals were temporarily anesthetized using appropriate dosages of Telazol ${ }^{\circledR}$ (which combines the anesthetic drug tiletamine $\mathrm{HCl}$ with the benzodiazepine anxiolytic drug, zolazepam $\mathrm{HCl}$ ). All individuals were released in the afternoon or early evening at the site of capture.

During the eight months slotted for random sampling, five smaller grids (each measuring approximately $20 \times 20$ $\mathrm{m}^{2}$ ) were set at randomly selected places within each of the three forests. Nine traps were set in each of the five grids at heights of one to two meters (spaced ca. $10 \mathrm{~m}$ apart) and three additional traps were set on the ground. Trapping occurred for five days per week for three consecutive weeks (for a total of 900 traps per forest per month). Trapping locations were flagged and their positions recorded using GPS. The above procedures were followed whenever individuals were found in the traps. At the end of each of the eight months devoted to random sampling, we conducted intensive sampling following

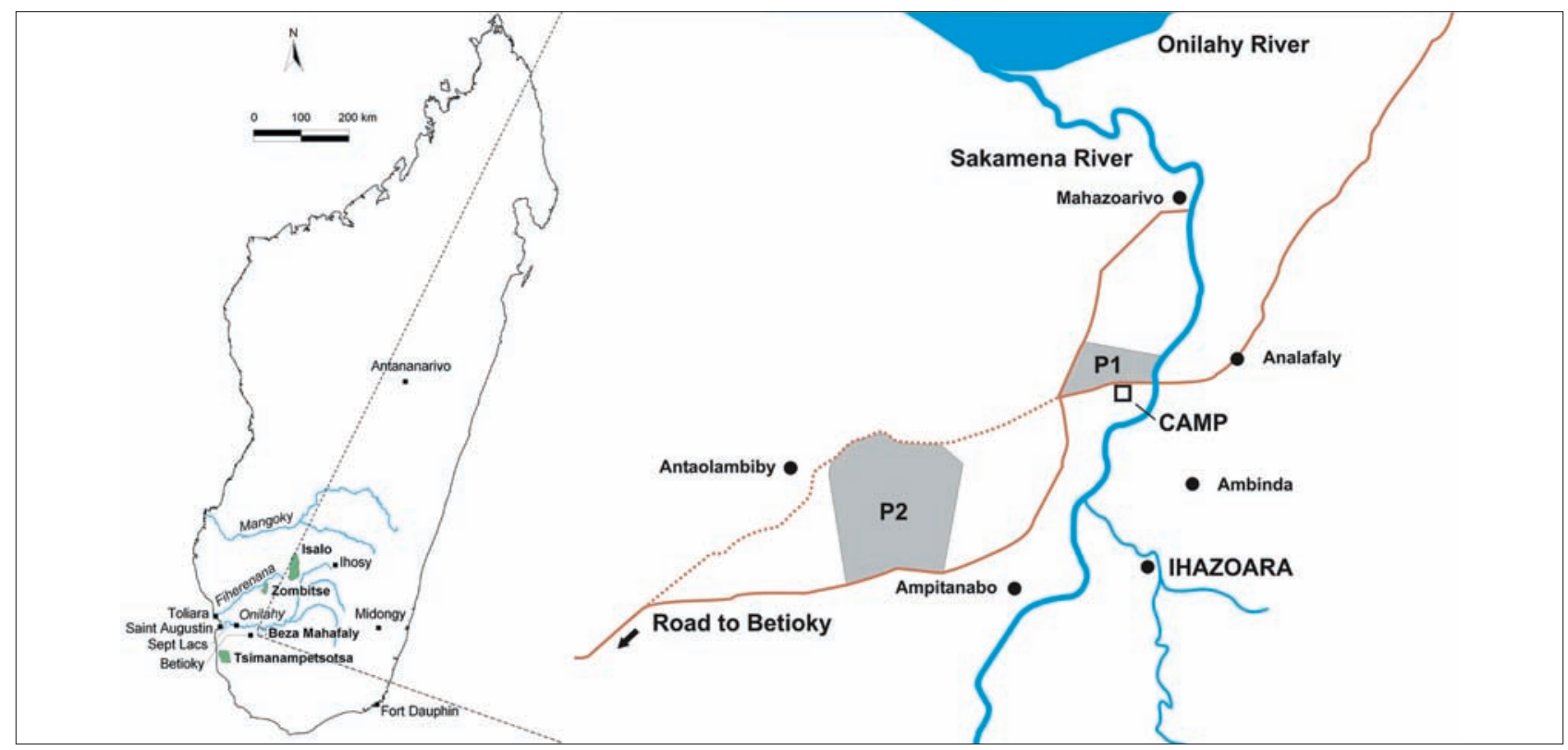

FIGURE 1. Map of Beza Mahafaly showing the locations of Parcel 1, Parcel 2, Ihazoara village (with forest to the south of the village) and other nearby villages. 
the procedures laid out above over a three day period in the standard sampling grid, for an additional total of $180 \times 3$ traps per forest site per month.

In total, we set 33,120 traps in each of the three forests (or 99,360 traps in all three forests) over the entire year. There were two months of intensive capture (October and January) in the 'wet season' and two (May and September) in the 'dry season' plus eight months of random capture (four in each season). To make the data comparable across months, we converted numbers of individuals captured to capture success rates, taking into account the number of traps set in each month.

Simultaneously, 20 traps were set each night at three villages - Mahazoarivo north of Parcel 1, Ampitanabo southeast of Parcel 2, and Ihazoara northwest of the Ihazoara Forest (Figure 1). An additional 20 traps were set each night at the research campsite adjacent to Parcel 1. These traps were placed randomly within the villages and the camp. They were checked in the morning and trapped animals were brought to the campsite for measurement.

All precautions were followed to help prevent the spread of disease. For example, occupied traps were cleaned with soap and water before being reused for the following night's trapping. Animal handlers wore gloves when handling the animals. If traps were empty, their doors were closed and the banana bait was discarded.

\section{RESULTS}

Among the rodents captured were two endemic species Macrotarsomys bastardi $(n=3)$ and Eliurus myoxinus $(n=1)$, numbers that pale in comparison to the numbers of Rattus rattus and Mus musculus simultaneously captured not only in areas of human occupation, but also in gallery forest. The endemic rodents were trapped only in Parcel 1 (gallery forest), and never in any of the villages or in the two drier forest habitats. The total number of endemic rodents trapped during the entire year in the three study forests represents less than $5 \%$ of the total number of introduced rodents that entered the traps. In total (excluding recaptured individuals), we captured 254 Microcebus griseorufus, 59 Rattus rattus, 46 Echinops telfairi, 32 Mus musculus, 1 Eliurus myoxinus, and 3 Macrotarsomys bastardi.

Many more rats and mice were captured at the three villages (generally between one and two per night at each site), but no endemic species (Microcebus griseorufus, Echinops telfairi, Eliurus myoxinus, or Macrotarsomys bastardi) were ever captured within the boundaries of the three villages. At the camp proper, rats were captured approximately every other day. Rats entered the kitchen and the camping area (where researchers and tourists set up their tents); no other species were captured in traps set within the camp. In July 2005 a pair of Microcebus was captured in a trap set in a Sasavy tree (Salvadora angustifolia, Salvadoraceae) near the outdoor kitchen; this pair was observed in the same tree during the year 2006-2007, but did not enter any of the traps set in the camp.

Within the forests proper, mouse lemurs entered traps repeatedly. Of 254 mouse lemurs captured during the year, 70 (27.7\%) were captured twice or more. Of the 59 Rattus rattus captured in forests during the year, 24 (40.7\%) were recaptured. None of the individuals of the other species were recaptured. Here we limit comparisons to data on the number of first captures by location and month (Table 1).
TABLE 1. Total captures, by forest, month, and species. Dark coloured months represent intensive capture schedules. For each of these months at each site, 5,400 traps were set. For (un-bolded) random capture months, 1,440 traps were set at each site.

A. Parcel 1 captures per month per species

\begin{tabular}{|l|c|c|c|c|c|c|c|c|c|c|c|c|}
\hline Genus & Oct & Nov & Dec & Jan & Feb & Mar & Apr & May & Jun & Jul & Aug & Sept \\
\hline Rattus & 12 & 6 & 3 & 0 & 0 & 0 & 2 & 1 & 8 & 10 & 6 & 4 \\
\hline Mus & 2 & 1 & 0 & 0 & 0 & 0 & 0 & 3 & 1 & 1 & 2 & 3 \\
\hline Eliurus & 0 & 0 & 0 & 0 & 0 & 0 & 0 & 0 & 1 & 0 & 0 & 0 \\
\hline Macrotarsomys & 0 & 0 & 0 & 0 & 0 & 0 & 0 & 1 & 2 & 0 & 0 & 0 \\
\hline Echinops & 2 & 1 & 5 & 3 & 4 & 1 & 0 & 0 & 0 & 0 & 0 & 0 \\
\hline Microcebus & 10 & 0 & 3 & 13 & 0 & 0 & 2 & 38 & 16 & 26 & 6 & 4 \\
\hline
\end{tabular}

B. Parcel 2 captures per month per species

\begin{tabular}{|l|c|c|c|c|c|c|c|c|c|c|c|c|}
\hline Genus & Oct & Nov & Dec & Jan & Feb & Mar & Apr & May & Jun & Jul & Aug & Sept \\
\hline Rattus & 0 & 0 & 0 & 0 & 0 & 0 & 0 & 0 & 1 & 0 & 1 & 0 \\
\hline Mus & 0 & 0 & 0 & 0 & 0 & 0 & 0 & 0 & 0 & 0 & 0 & 0 \\
\hline Eliurus & 0 & 0 & 0 & 0 & 0 & 0 & 0 & 0 & 0 & 0 & 0 & 0 \\
\hline Macrotarsomys & 0 & 0 & 0 & 0 & 0 & 0 & 0 & 0 & 0 & 0 & 0 & 0 \\
\hline Echinops & 0 & 1 & 5 & 2 & 7 & 4 & 1 & 1 & 0 & 0 & 0 & 0 \\
\hline Microcebus & 10 & 3 & 1 & 1 & 0 & 1 & 1 & 35 & 4 & 4 & 8 & 2 \\
\hline
\end{tabular}

C. Ihazoara captures per month per species

\begin{tabular}{|l|c|c|c|c|c|c|c|c|c|c|c|c|}
\hline Genus & Oct & Nov & Dec & Jan & Feb & Mar & Apr & May & Jun & Jul & Aug & Sept \\
\hline Rattus & 1 & 1 & 0 & 0 & 0 & 0 & 0 & 1 & 0 & 2 & 0 & 0 \\
\hline Mus & 3 & 4 & 1 & 2 & 0 & 0 & 0 & 0 & 1 & 1 & 3 & 4 \\
\hline Eliurus & 0 & 0 & 0 & 0 & 0 & 0 & 0 & 0 & 0 & 0 & 0 & 0 \\
\hline Macrotarsomys & 0 & 0 & 0 & 0 & 0 & 0 & 0 & 0 & 0 & 0 & 0 & 0 \\
\hline Echinops & 1 & 2 & 1 & 3 & 0 & 0 & 0 & 0 & 0 & 0 & 0 & 0 \\
\hline Microcebus & 5 & 1 & 1 & 2 & 2 & 3 & 8 & 15 & 9 & 4 & 6 & 1 \\
\hline
\end{tabular}

Figure 2 shows a breakdown of capture success for the three most frequently trapped species by forest and month. Individual species showed strikingly different capture patterns across months, and sometimes by location. Rattus rattus was significantly more prevalent within Parcel 1 than at either of the other forests (ANOVA of capture success / month by location for rats only: $F=9.4$, df $(2,33), p=0.001)$. Rattus was not captured at any forest during the wettest months (January through March) when food at all sites was abundant. In contrast, Echinops was captured most often in the spiny forest, but not at all during the months of June through September, when it hibernates. Microcebus tended to be captured in relatively high numbers at all three forests (with no significant difference in capture success, but with the highest mean success rate in the gallery forest). They were captured throughout the year, but least often during the months of February and March (again during the wet season, when food was abundant). Neither females nor males enter seasonal torpor (as occurs in certain other cheirogaleid species; Schmid and Kappeler 1998, Atsalis 1999 and 2008, Rasoazanabary 2006), so both males and females were frequently captured during the dry season (April through 

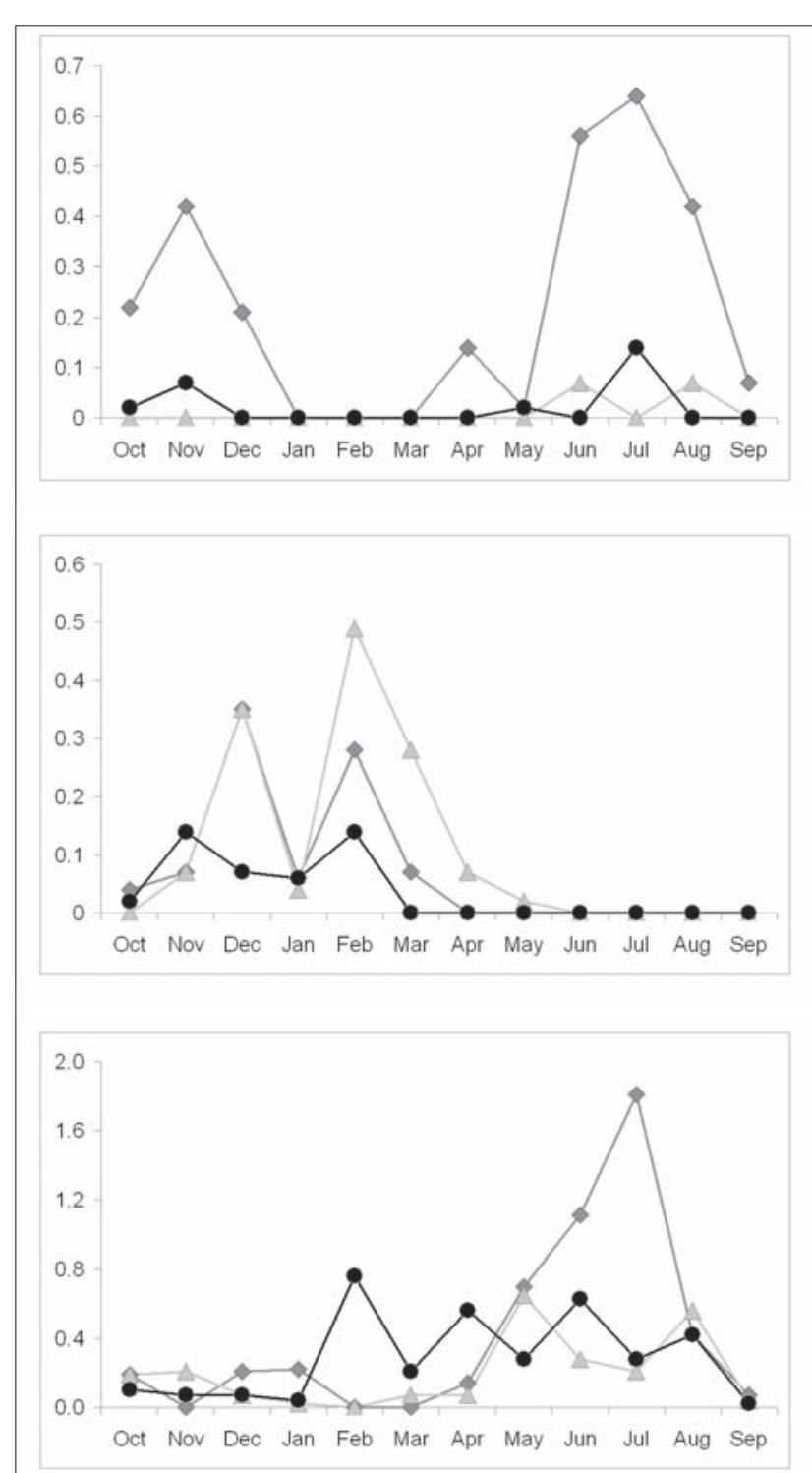

\section{$\rightarrow$ Parcel \#1 \\ - Parcel \#2 \\ - Ihazoara}

FIGURE 2. Capture success (\%) by month at three forest locations for the three most abundant species: Rattus rattus (top graph), Echinops telfairi, Microcebus griseorufus (bottom graph).

September). The abundance of $M$. griseorufus in the gallery forest was unexpected, as this species of mouse lemur is found only in spiny forests at Berenty in southern Madagascar while another species of Microcebus (M. murinus) inhabits the gallery forest (e.g. Yoder et al. 2002). There is no evidence of the presence of M. murinus at Beza Mahafaly (Heckman et al. 2006), and M. griseorufus also occurs in the gallery forest.

Less frequently captured were Mus, Eliurus, and Macrotarsomys; Mus musculus was never found in the spiny forest, but it was captured at Ihazoara forest and, somewhat less frequently, in Parcel 1. Macrotarsomys bastardi was captured only at the gallery forest (Parcel 1) and only during the months of May (one female) and June (one male and one female). Eliurus myoxinus was also captured in the gallery forest during the month of June (one juvenile male).
Species differed significantly in their capture totals in both the 'dry' season [April to September, ANOVA F = 11.2, df $(5,12)$, $p<$ 0.001 ], and the 'wet' season [October to March, ANOVA F $=6.3$, df $(5,12), p=0.004]$ with mouse lemurs showing high capture frequencies at all locations, and the two endemic rodent species showing low capture frequencies at all locations (indeed, no captures in Parcel 2 or Ihazoara regardless of season).

Table 2 shows the frequencies of successful trapping on the ground as opposed to 1-2 m above the ground, by species and site. During the months of intensive capture, because 150 traps were set in the trees and 30 on the ground, the expected capture success rate, if indeed there was no preference for ground vs. trees, is $5: 1$ (trees: ground). During all other months, the ratio of traps set in the trees to on the ground was 3:1.

It was not surprising that mouse lemurs (Microcebus griseorufus, which are highly arboreal) were most frequently trapped above the ground. However, it is also interesting that mouse lemurs were trapped regularly (19.8\% of all captures) on the ground. Ground captures for mouse lemurs were most frequent during the dry season. Behavioral observations of radio-collared mouse lemurs by one of the authors (ER, unpublished data) demonstrated a tendency of mouse lemurs at Beza to descend to the ground, especially in protected forests. This behavior was observed in association with feeding on insects and drinking water, both in the gallery and spiny forests. Rats were captured in ratios of $3: 2$ (36 captures in the trees to 23 on the ground). Introduced rats appear to be invading arboreal niches in the forests of Madagascar, at least at Beza Mahafaly. In contrast, $78.1 \%$ of Mus musculus captures were in traps located on the ground. All captures of the endemic rodents, Macrotarsomys bastardi and Eliurus myoxinus, were on the ground, as were all captures of the tenrec Echinops telfairi. According to behavioral observations made by Salton (2005), Echinops telfairi is one of the more arboreal of tenrecoids (see also Salton and Szalay 2004, Salton and Sargis 2008), and it is therefore perhaps surprising that none of its captures were above the ground. Salton (2005) regularly observed Echinops at Beza Mahafaly in the trees, between one and two meters off the ground. However, like other tenrecoids, Echinops do spend a fair amount of time on the ground, and they can be found resting under logs and sometimes hibernating under tree roots in holes in the ground (Salton 2005, IAJY pers. obs.).

Morphometric data collected for Macrotarsomys bastardi and the other small-bodied mammals at Beza Mahafaly are provided in Table 3. This species is about twice as large as Mus musculus but only one fifth the size of sympatric Rattus rattus. As expected of Macrotarsomys bastardi, the head is relatively large, and the tail is relatively long (approximately one third longer than the combined length of the head and body). The ears and feet are relatively large. Ear length averaged $17.7 \mathrm{~mm}$. The hindfoot is $80 \%$ as long as the head. The dorsal coat is gray-brown (less brown and more gray than in Rattus); the ventrum is whitish and has less of a yellow hue than that of sympatric Rattus. The tail matches the color of the dorsal fur but is somewhat darker; it lacks the distinctive hairy tuft present on the tails of Eliurus. specific dimensions closely match those of Macrotarsomys bastardi from other sites (Goodman et al. 2006). Our three individuals varied in weight from 18 to $23 \mathrm{~g}$; Carleton and Goodman (2003) and Goodman et al. (2006) report a weight range of 21-28 $\mathrm{g}$ for adult $M$. bastardi; the mean adult mass is $24.5 \mathrm{~g}$. 
TABLE 2. Frequency of successful 'trapping on the ground' versus '1-2 meters above the ground', grouped by species and site.

\begin{tabular}{|c|c|c|c|c|c|c|}
\hline Genus & Parcel 1 (ground) & Parcel 1 (tree) & Parcel 2 (ground) & Parcel 2 (tree) & Ihazoara (ground) & Ihazoara (tree) \\
\hline Rattus & 21 & 31 & 0 & 2 & 2 & 3 \\
\hline Mus & 11 & 2 & 0 & 0 & 14 & 5 \\
\hline Eliurus & 1 & 0 & 0 & 0 & 0 & 0 \\
\hline Macrotarsomys & 3 & 0 & 0 & 0 & 0 & 0 \\
\hline Echinops & 16 & 0 & 21 & 0 & 9 & 0 \\
\hline Microcebus & 29 & 89 & 9 & 61 & 12 & 54 \\
\hline
\end{tabular}

TABLE 3. Morphometric data of nocturnal mammals at Beza Mahafaly, excluding infants and juveniles except where noted ( $N$, mean, and, in parentheses, standard deviation)

\begin{tabular}{|c|c|c|c|c|c|c|c|}
\hline Genus and species & $\mathrm{N}$ & Body mass (g) & Head length (mm) & Body length (mm) & Tail length (mm) & Foot length (mm) & Ear length (mm) \\
\hline Rattus & 49 & $106(17.6)$ & $45.4(3.5)$ & $113.1(13.7)$ & $117.2(25.9)$ & $31.6(2.5)$ & $21.5(1.3)$ \\
\hline Mus & 30 & $11.7(1.9)$ & $24.7(1.4)$ & $50.3(6.7)$ & $70.7(6.1)$ & $15.3(1.2)$ & $12.1(1.2)$ \\
\hline Eliurus* & 1 & $23.0--$ & $31.6--$ & $55.0--$ & $120.0--$ & $25.0--$ & $20.6--$ \\
\hline Macrotarsomys & 3 & $19.7(2.9)$ & $33.8(1.8)$ & $74.0(1.7)$ & $143.0(34.0)$ & $27.5(1.3)$ & $17.7(1.0)$ \\
\hline Echinops & 35 & $83.7(5.6)$ & $42.2(1.3)$ & $119.2(17.4)$ & 0 & $16.6(0.6)$ & $19.6(1.5)$ \\
\hline Microcebus & 154 & 50.7 (9.9) & $33.6(1.7)$ & $91.9(9.5)$ & $144.6(11.0)$ & $29.5(3.2)$ & $22.1(1.3)$ \\
\hline
\end{tabular}

*This individual is a juvenile.

\section{DISCUSSION}

Macrotarsomys bastardi has a wide geographic distribution and is not considered endangered. However, it may be rare in certain parts of its range. Several other species of Macrotarsomys ( $M$. ingens 64.5 g, M. petteri 105 g.) have a very restricted geographical range; indeed, the largest of the big-footed mice, M. petteri, was only recently described on the basis of the capture of a single individual in the forest of Mikea near the west coast of Madagascar (north of Toliara) (Goodman and Soarimalala 2005). From subfossil material, we can now consider that this species also occurred in southeastern Madagascar not long ago as its bones were found in the subfossil Holocene fauna of Andrahomana, a cave in southeastern Madagascar approximately $460 \mathrm{~km}$ away from the capture site in the Mikea forest (Goodman et al. 2006, Burney et al. 2008)

Despite years of fieldwork by numerous field researchers at Beza Mahafaly Special Reserve, Macrotarsomys bastardi has never previously been reported here. Nocturnal surveys and trapping were first conducted at Beza in 2002 during the rainy season, and subsequently in 2003 and 2004 during the dry season. Rats were observed in trees as well as on the ground; in July, 2003, ER found two rats in traps set (for Microcebus) at heights of about two meters above ground within the gallery forest. Intensive trapping was later initiated in October 2006; it was continued thereafter through the end of September 2007. During that year, many rats and mouse lemurs were captured and marked, but it was only then and indeed only during a two-month interval within that period (May and June 2007 - the early dry season) that endemic rodents were also successfully trapped. At Morondava, reproductive activity of Macrotarsomys bastardi peaks in April and May (Ganzhorn 2003). It is possible that it peaks a bit later at Beza, which is located considerably further to the south (393 km); thus the captures in May and June may correspond to the breeding season.

The fact that Macrotarsomys bastardi and Eliurus myoxinus were trapped in such low numbers signals their possible endangerment at Beza Mahafaly. Nevertheless, it is interesting to note that endemic small mammals do persist in small forest patches in Madagascar. It is noteworthy that Goodman et al. (1993) reported no endemic rodent presence in pellet samples of the Long-eared owl (Asio madagascariensis) collected just outside the reserve at Beza Mahafaly on the bank of the Ihazoara River during the year 1990. Pellet samples were collected during both wet and dry seasons (March, April, June and November). In contrast, at Bezavona (near Nahampoana, in southeast Madagascar, near Taolognaro), bones of two species of Eliurus (along with introduced rodents and other small mammals) were found in the pellets of the same owl, so it is unlikely that these rodents are unattractive to this formidable predator.

one of the factors that may influence capture frequencies is variation in diet. However, many rodents are attracted to banana, and should be lured by traps baited with banana. Rats and mice consume fruit as well as seeds, insects, and leaves, and both readily enter traps, particularly when set at low levels or on the ground. Macrotarsomys bastardi is strictly nocturnal and terrestrial, and similarly feeds on seeds and fruit (Carleton and Goodman 2003, Ganzhorn 2003).

Incidentally, cheirogaleus medius has been listed as present at Beza Mahafaly (e.g. Mittermeier et al. 2006), but this is likely an error. This species has never been observed by researchers working on nocturnal mammals at Beza; bones of this species have not been recorded in owl pellets (largely Microcebus; see Goodman et al. 1993), and no Cheirogaleus entered traps set at any height during this study. It is unlikely 
that diet explains this absence, as Cheirogaleus covets banana and is easily trapped in arboreal settings at other sites (e.g. Müller 1999, Blanco et al. in press).

Interactions among introduced and endemic small mammals will require further analysis. Ganzhorn (2003) studied the interactions of these species in the region of Morondava, and found that Macrotarsomys likes primary forests with a high density of trees of all diameters; it was never found in fragments smaller than 600 ha while rats tend not to like forests of large size, particularly those with trees of large diameter; instead, they prefer small forests with trees of moderate $(5-9.9 \mathrm{~cm}$ ) diameter (Ganzhorn 2003). At Beza Mahafaly, however, there are no large forests, and M. bastardi persists in small gallery forests. Over a century ago, Guillaume Grandidier (1902) described Macrotarsomys bastardi as found regularly in gallery forests bordering streams or rivers in southern Madagascar, alongside the very common Lemur catta.

The gallery forest at Beza is fairly disturbed; despite its being fenced, cattle are able to enter, and indeed, night and day, they are sometimes deliberately hidden in the gallery forest by local villagers to protect them from thieves. It is quite a bit smaller than 600 ha (Parcel 1 is only about 90 ha; Anne Axel, pers. comm.). The western portion of Parcel 1 is distant from the river and is correctly classified not as gallery forest but as transitional dry forest (Anne Axel, pers. comm.). Gallery forest extends beyond the confines of Parcel 1 to the north and south along the bank of the Sakamena River, but even so, the total area of gallery forest is not more than 115 ha (Anne Axel, pers. comm.).

Rats may be attracted to Parcel 1 at Beza simply because it is disturbed; these rodents may prefer habitats near human occupation, despite their existence in undisturbed forests in Madagascar. At Beza, both introduced rodents and big-footed mice are found on the ground, where they consume similar foods. In our study, rodents (whether endemic or introduced) were very rarely captured in the spiny forest, but Echinops was well represented there, as was Microcebus griseorufus. In the gallery forest where endemic and introduced rodents were found, the possibility that introduced rodents are having a negative impact on endemic species such as Macrotarsomys bastardi cannot be dismissed. We need to collect ecological data to record more directly possible negative interactions.

To further test the degree to which small endemic mammals are endangered at Beza Mahafaly, a broader trapping effort covering other parts of the three forests is certainly warranted; whereas our sampling effort was intensive, our sampling areas were rather small. Several species of small mammals that are known to exist at Beza Mahafaly (including Geogale aurita, Setifer setosus, and Suncus etruscus madagascariensis; Ratsirarson et al. 2001) never entered our traps. However, in the vicinity of the reserve, in 2003, Justine Salton and Rochelle Buffenstein had considerable success capturing Echinops telfairi in pitfall traps, which they used in addition to Sherman traps (Salton and Buffenstein 2004); they also captured Geogale auritus and Setifer setosus in a variety of traps. Thus we propose that, to maximize capture success, a wider variety of trap types, trap locations, and trap baits should be systematically tested. Certain species may prefer peanut butter, dried fish, or fresh meat to bananas. For ground traps, the type of ground habitat (e.g. distance to fallen logs, density of leaf litter) may be important (Stephenson 1994). For traps set in trees, the tree species and dimensions of the tree may be important.
Finally, traditional techniques for collecting behavioral data (including radio-tracking) should be employed to study interspecific interactions. If it can be shown that introduced rodents are indeed negatively impacting native species, a program of systematic eradication of Rattus and Mus should be considered.

\section{CONCLUSIONS}

A study of the small nocturnal mammals at Beza Mahafaly, involving a year - long effort of ground and tree capture, revealed the presence here of a species never before at this site, and the relative abundance of introduced rats and mice at this site. For the first time, Macrotarsomys bastardi was found in the gallery forest of Beza Mahafaly. We found no Cheirogaleus at Beza Mahafaly.

While rats and mice were infrequently (or never, in the case of mice) found in the spiny forest, and were most abundant in villages, rats and mice were both present in dry and gallery forests near villages or campsites.

Echinops telfairi and Microcebus griseorufus occur at Beza Mahafaly in both spiny and gallery forest; Microcebus griseorufus was more often trapped in the trees whereas Echinops was trapped exclusively on the ground (although it does climb trees, and has been trapped there in previous years). Although rats climb trees, they are frequently found on the ground. In contrast, endemic rodents were always trapped on the ground (Macrotarsomys bastardi is strictly terrestrial). Mus were also trapped on the ground far more frequently than in the trees.

Endemic rodents may occur at Beza in low density. We captured many more individuals belonging to introduced than endemic rodent species over a period of one year of intensive and random trapping. Introduced rodents may have negatively impacted endemic species at this site.

\section{ACKNOWLEDGEMENTS}

Many people helped with this research. For facilitating our study, we thank ANGAP, ESSA, and the Chief of BMSR. We are grateful to the following people who helped us collect the data: Viviane, Tsibara, Edward, Elahavelo, Efitiria, Enafa, Edabo, Dada, Etinahy, Filaoke, Fanomezana, Etala, Ebolo. We also thank the many local villagers who set the traps for rats and mice in and near their homes and who brought specimens to our campsite. Anne Axel generously provided unpublished data, and Darren Godfrey drew the map of Beza Mahafaly (Figure 1). Laurie Godfrey helped with the English and with statistical analysis of the data, and Natalie vasey along with anonymous reviewers offered helpful comments on an earlier version of this manuscript. This research was funded by the International Foundation for Science, Wildlife Conservation Society, National Geographic Society, Primate Conservation, Inc. and the American Primatological Society (to Emilienne Rasoazanabary), as well as funds from the Universities of North Dakota and Massachusetts supporting Jacky Youssouf's travel to the USA.

\section{REFERENCES}

Atsalis, S. 1999. Seasonal fluctuations in body fat and activity levels in rainforest species of Mouse lemur, Microcebus rufus. International Journal of Primatology 20, 6: 883-910.

Atsalis, S. 2008. A Natural History of the Brown Mouse Lemur. Pearson/ Prentice Hall: Upper Saddle River, New Jersey.

Blanco, M. B., Godfrey, L. R, Rakotondratsima, M., Rahalinarivo, V., Samonds, K. E., Raharison, J.-L. and Irwin, M. T. In press. Discovery of sympatric 
Dwarf lemur species in the high-altitude rainforest of Tsinjoarivo, eastern Madagascar: Implications for biogeography and conservation. Folia Primatologica.

Burney, D. A., Vasey, N., Godfrey, L. R., Ramilisonina, Jungers, W. L., Ramarolahy, M. and Raharivony, L. 2008. New findings at Andrahomana Cave, southeastern Madagascar. Journal of Cave and Karst Studies 70 , 1: $13-24$.

Carleton, M. D. and Goodman, S. M. 2003. Macrotarsomys, Big-footed Mice. In: The Natural History of Madagascar, S. M. Goodman and J. P. Benstead (eds.), pp. 1386-1388. The University of Chicago Press, Chicago.

Carleton, M. D. and Schmidt, D. F. 1990. Systematic studies of Madagascar's endemic rodents (Muroidea: Nesomyinae): An annotated gazetteer of collecting localities of known forms. American Museum Novitates 2987: 1-36

Ganzhorn, J. U. 2003. Effects of introduced Rattus rattus on endemic small mammals in dry deciduous forest fragments of western Madagascar. Animal Conservation 6, 2: 147-157.

Garbutt, N. 2007. Mammals of Madagascar: A Complete Guide. Yale University Press: New Haven.

Goodman, S. M. and Soarimalala, V. 2005. A new species of Macrotarsomys (Rodentia: Muridae: Nesomyinae) from southwestern Madagascar, Proceedings of the Biological Society of Washington 118, 2: 450-464.

Goodman, S. M., Langrand, O. and Raxworthy, C. J. 1993. Food habits of the Madagascar long-eared owl Asio madagascariensis in two habitats in southern Madagascar. Ostrich 64, 2: 79-85.

Goodman, S. M., Vasey, N. and Burney, D. A. 2006. The subfossil occurrence and paleoecological implications of Macrotarsomys petteri (Rodentia: Nesomyidae) in extreme southeastern Madagascar. Comptes Rendus Palevol 5, 8: 953-962.

Goodman, S. M., Raherilalao, M. J., Rakotomalala, D., Rakotondravony, D. Raselimanana, A. P., Razakarivony, H. V. and Soarimalala, V. 2002. Inventaire des vertébrés du Parc National de Tsimanampetsotsa (Toliara). Akon'ny Ala 28: 1-36.

Grandidier, G. 1902. Une mission dans la région australe de Madagascar en 1901. La Géographie 6: 1-16

Heckman, K. L., Rasoazanabary, E., Machlin, E., Godfrey, L. R. and Yoder, A. D. 2006. Incongruence between genetic and morphological diversity in Microcebus griseorufus of Beza Mahafaly. BMC Evolutionary Biology 6: 98. <www.biomedcentral.com/1471-2148/6/98>.

IUCN 2008. Macrotarsomys bastardi 2008 IUCN Red List of Threatened Species. <Www.iucnredlist.org> accessed 27 October 2008.

Jansa, S. A., Soarimalala, V., Goodman, S. M. and Barker, F. K. 2008. Morphometric variation and phylogeographic structure in Macrotarsomys bastardi (Rodentia: Nesomyidae), an endemic Malagasy dry forest rodent. Journal of Mammalogy 89, 2: 316-324.

Mittermeier, R. A., Konstant, W. R., Hawkins, F., Louis, E. E., Langrand, O., Ratsimbazafy, J., Rasoloarison, R., Ganzhorn, J. U., Rajaobelina, S., Tattersall, I. and Meyers, D. M. 2006. Lemurs of Madagascar (second edition). Conservation International, Washington, D.C.

Müller, A. E. 1999. Aspects of social life in the Fat-tailed dwarf lemur (Cheirogaleus medius): Inferences from body weights and trapping data. American Journal of Primatology, 49: 265-280.

Rakotondravony, D. 1996. Biogéographie des Rongeurs de Madagascar. In: Biogéographie de Madagascar/Biogeography of Madagascar, W. R. Lourenço (ed.), pp. 303-306. ORSTOM: Paris.

Rasoazanabary, E. 2006. Male and female activity patterns in Microcebus murinus during the dry season at Kirindy Forest, western Madagascar. International Journal of Primatology 27, 2: 437-464.

Rasoma, J. and Goodman, S. M. 2007. Food habits of the Barn owl Tyto alba in spiny bush habitat of arid southwestern Madagascar. Journal of Arid Environments 69, 3: 537-543.

Ratsirarson, J., Randrianarisoa, J., Ellis, E., Emady, R. J., Efitroarany, Ranaivonasy, J., Razanajaonarivalona, E. H. and Richard, A. F. 2001. Bezà Mahafaly: écologie et réalités socio-économiques. Recherches Pour le Développement, Série Sciences biologiques 18: 1-104.

Ratsirarson, J. 2003. Réserve Spéciale de Beza Mahafaly. In: The Natural History of Madagascar. S. M. Goodman and J. P. Benstead (eds.), pp. 1522-1525. The University of Chicago Press, Chicago.
Salton, J. A. 2005. Evolutionary Morphology of The Postcranial Skeleton in Afro-Malagasy Tenrecoidea (Mammalia). PhD Dissertation, City University of New York.

Salton, J. A. and Buffenstein, R. 2004. Field Thermoregulatory Profiles in Tenrecs from the Rainforest and Xeric forest of Madagascar. Poster presented at the Society for Integrative and Comparative Biology Annual Meeting, New Orleans, LA.

Salton, J. A. and Sargis, E. J. 2008. Evolutionary Morphology of the Tenrecoidea (Mammalia) Forelimb Skeleton. In: Mammalian Evolutionary Morphology. A Tribute to Frederick S. Szalay. E. J. Sargis and M. Dagosto (eds.), pp. 51-71. A Tribute to Frederick S. Szalay, Springer Science + Business Media, New York.

Salton, J.A. and Szalay, F. S. 2004. The tarsal complex of Afro-Malagasy Tenrecoidea: A search for phylogenetically meaningful characters. Journal of Mammalian Evolution 11: 73-104.

Schmid, J. and Kappeler, P. M. 1998. Fluctuating sexual dimorphism and differential hibernation by sex in a primate, the Gray mouse lemur (Microcebus murinus). Behavioral Ecology and Sociobiology 43, 2 : 125-132.

Stephenson, P. J. 1994. Seasonality effects on small mammal trap success in Madagascar. Journal of Tropical Ecology 10, 3: 439-444.

Yoder, A. D., Burns, M. M. and Génin, F. 2002. Molecular evidence of reproductive isolation in sympatric sibling species of Mouse lemurs. International Journal of Primatology 23, 6:1335-1343. 